\title{
İs Tatmini ile Alt Boyutları Arasındaki ilişskiler ve Demografik Faktörlerin Bu Değişkenler Üzerindeki Etkisi: Görgül Bir Araştırma
}

\author{
Relationships Between Job Satisfaction and its Sub Dimensions and the Effect of \\ Demographic Factors on These Variables: An Empirical Research
}

\begin{abstract}
Tamer KILIÇ ${ }^{1}$
Ihsan SAYGILI ${ }^{2}$

Öz

Bu çalışmanın amacı; havacılık bakım merkezlerinde görevli çalışanların iş tatmini düzeylerini araştırmak, iş tatmini ile dokuz alt boyutu arasındaki ilişkileri incelemek ve demografik faktörlerin iş tatminine ve alt boyutlarına etkilerini analiz etmektir. Bu kapsamda, kamu ve özel kurum ve kuruluşların hava araçlarına bakım hizmeti sağlayan Ankara'daki havacııık bakım merkezlerinde çalışan iş görenlere anket uygulanmıştır. Araştırma sonucunda çalışanların; genel olarak işlerinden memnun oldukları, özellikle ücret, ödül ve arkadaşlarına ilişkin tatmin düzeylerinin ortalamanın üzerinde çıktığı görülmüştür. Diğer taraftan demografik değişkenlerden cinsiyet, medeni durum, eğitim durumu, toplam çalışma süresi ve unvan farklııklarının çalışanların tatmin düzeyini önemli ölçüde etkilediği tespit edilmiştir. Özellikle cinsiyet durumuna göre kadın ve erkek çalışanların iş tatmininin alt boyutlarından "iletişim ve kariyer-yükselme" ile ilgili algılarının farklı olduğu belirlenmiş̧ir. Ayrıca çalışanların medeni durumuna (evli veya bekâr olmalarına) göre iş tatmininin alt boyutlarından "iletişim, sosyal haklar ve kariyer-yükselme" algılarının da farklılaştı̆ıı anlaşılmışır.
\end{abstract}

Anahtar Kelimeler: İ̧̧ tatmini, kariyer-yükselme, sosyal haklar, demografik değişkenler, havacılık bakım merkezi.

\section{ABSTRACT}

The aim of this study is to investigate job satisfaction levels of employees working in aviation maintenance centers, and to examine the relationship between job satisfaction and its nine sub-dimensions and to analyze the effects of demographic factors on these variables. In this context, a questionnaire was applied to those working in the aviation maintenance centers in Ankara. As a result of the research, it is determined that people working in these maintenance centers are satisfied with their jobs in general. It is found that the satisfaction levels of employees especially about wages, rewards and their friends are above the average. On the other hand, it is also determined that differences in demographic variables such as gender, marital status, education level, total working time (hours) and job title have significant impacts on employee satisfaction. In particular, it is ascertained that the perception of the male and female employees by gender is different in terms of communication and careerpromotion which are sub-dimensions of job satisfaction. In addition, it is also understood that according to the marital status of employees (being married or single), their perceptions about some sub-dimensions of job satisfaction (which are communication, social rights and career-promotion) differ.

Keywords: Job satisfaction, career-promotion, social rights, demographic variables, aviation maintenance center. 


\section{GíRIŞ}

Rekabetin yoğun olduğu günümüz iş dünyasında işletmelerin başarılı olabilmesi için motive olmuş nitelikli iş gücü; örgütsel anlamda esneklik, çevreye uyum ve rekabet üstünlüğü sağlayan önemli bir değişkendir. Bu nedenle işletmeler çalışanlarına önemli yatırımlar yapmakta, koşulsuz müşteri memnuniyeti için yoğun çaba göstermektedirler. $\mathrm{Bu}$ kapsamda çalışanların işlerine karşı duydukları memnuniyet, işletmeler tarafından önemli bir girdi olarak kabul edilmektedir. Zira iş görenlerin (çalışanların) memnuniyeti (iş tatmini) performanslarına yansımakta (Pekdemir vd., 2006, s.15), performans artışı da müşteri memnuniyetine katkı sağlamaktadır.

İşletmeler, müşterilere kaliteli hizmet sunabilmek için nitelikli personel istihdam etmek durumundadır. Ancak nitelikli personel istihdamının yanı sıra, çalışanların memnuniyeti de müşteriye sunulacak hizmetin kalitesini doğrudan etkilemektedir (Pierchy, 1998). İşgörenlerin günlük yaptığı işler sonucunda beklentilerine kavuşmasının, onları daha mutlu ettiği bilinmektedir (Bakan ve Büyükbeşe, 2004, s.6). Bu kapsamda iş görenlerin performans ve verimliliğini artırmak için iş tatmin düzeylerinin takip edilmesine ihtiyaç vardır. Verimli ve etkili insan gücü, işletmelerin faaliyetleri bakımından önemli bir girdi kabul edildiğinden (Akıncı, 2002, s.6), söz konusu çalışanların işletmede kalmaları için yaptıkları işlerden memnun olmaları ve iş tatminlerinin sağlanması önem arz etmektedir.

İş görenlerin memnuniyeti (iş tatmini) ile onların performansı ve verimliliği arasındaki ilişkiler yapılan araştırmalarla incelenmiş, bu kapsamda çok sayıda değişken farklı koşullarda ele alınarak çeşitli modeller ve teoriler ortaya atılmıştır. Örneğin Erdil ve arkadaşları (2004, s.18); yönetim tarzı, çalışma koşulları, arkadaşlık ortamı ve takdir edilme duygusu ile iş tatmini arasındaki ilişkileri araştırmışlardır.

$\mathrm{Bu}$ çalışmada öncelikle havacılık bakım merkezlerinde görevli çalışanların iş tatmini düzeylerini araştırmak, iş tatmini ile dokuz alt boyutu arasındaki ilişkileri incelemek ve demografik faktörlerin iş tatminine ve alt boyutlarına etkilerini analiz etmek amaçlanmıştır. Araştırma; çalışanların iş tatmini ile ilgili sorunlarına dikkat çekilmesi ve bu sorunların çözümüne ilişkin çalışmalara katkıda bulunması açısından önemlidir.

\section{KAVRAMSAL ÇERÇEVE}

Araştırma kapsamında yapılan çalışmaların ayrıntılarına geçmeden önce, konuya ilişkin temel kavram olan iş tatmini ile bu kavramı oluşturan dokuz alt boyutun içeriği ortaya konulacaktır.

\section{İș Tatmini}

İş tatmini, çalışanların işlerinden duydukları memnuniyeti ya da memnuniyetsizliği ifade eder (Davis, 1984; Spector, 1997, s.6; Muchinsky, 2006, Ertürk ve Keçecioğlu, 2012, s.40; Ergeneli ve Eryiğit, 2001, s.160)). Başka bir deyişle iş tatmini; çalışanın işinden beklediği, ümit ettiği ve hak ettiğini düşündüğü sonuçları, elde ettiği gerçek 
sonuçlarla karşılaştırması neticesinde ortaya çıkan duygusal bir tepkidir (Luthans, 1995, s.3; Oshagbemi,1997; Mercer,1997, s.58; Özdevecioğlu, 2004). Çalışanın işini sevmesi, işine bağlı olması ve kendini işine adaması sonucu duyduğu haz, hoşnutluk ve ruh durumu da iş tatmini olarak tarif edilir (Locke, 1983, s.97; Yücel ve Demirel, 2013; Arslan ve Demir, 2017, 374). Diğer taraftan çalışanların çalşstıkları iş yerleri ile ilgili benimsedikleri kendilerine özgü tutumlar da iş tatmini olarak tanımlanmıștır (Berry, 1997: Kantar, 2010). Locke (1969) iş tatmininin; çalışanın yaptığı isten beklediği ile iş sonucunda elde ettiklerinin bir fonksiyonu olduğunu savunmuştur. Davis (1984) işin nitelikleriyle çalışanların işlerinden beklentilerinin birbirine uyum gösterdiği durumlarda iş tatmininin gerçekleşebileceğini belirtmiştir (Davis, 1984, s.6).

Çalışanların yaptıkları işlerinden memnun olması (tatmin düzeylerinin yüksek olması), örgütsel verimliliğgi ve iş görenlerin örgütsel bağlılığını arttırır. İş tatmini yüksek olan iş görenler, zihinsel ve duygusal anlamda kendilerini iyi hissederler; örgütsel amaçların gerçekleştirilmesi için gayret sarf ederler ve müşterilerin memnuniyeti için çaba harcarlar. Çalışan memnuniyetinin yüksek olduğu işletmelerde işgücü devir hızı ve işe devamsızlık azaltır. (Tengilimoğlu, 2005, s.27; Aziri, 2011, s.85). İş görenlerin iş tatmin düzeyinin yüksek olması, çalışanlar, yöneticiler ve işletme için çeşitli yararlar sağlar.

Çalışanların iş ile ilgili içsel ve/veya dışsal durumlara ilişkin pozitif ya da negatif olarak hissettiği şeyler (Shahid, 2002, s.95) de iş tatmini olarak tarif edilir. İş görenlerin işe karşı olumlu ve arzu edilen davranışları iş tatmininin varlığına, olumsuz ve arzu edilmeyen davranışları ise iş tatminsizliğine işaret eder (Armstrong, 2006, s.264). Çalışanların işinde ve çalıştı̆̆ ortamda beklentilerini yeterince karşılanmadığını düşünmeye başlamasıyla birlikte iş tatminsizliği ortaya çıkmaktadır (Akıncı, 2002, s.3; Poyraz ve Kama, 2008, s.147). Başka bir ifade ile iş görenin iş deneyimleri sonucunda oluşan olumlu ruh hali iş tatmini; çalışanın işine karşı olumsuz tutumu ise iş tatminsizliği olarak ifade edilmektedir (Erdoğan, 1996, s.231)

Her çalışan, bir işletmede işe başladığında, ekonomik konuları içeren yazılı anlaşmanın yanında, yazılı olmayan duygusal (psikolojik) bir anlaşmayı da kabul eder. Güvenlik, insanca muamele görme, diğer çalışanlarla iyi ilişkiler kurma, önemsenme vb. beklentiler, yazılı olmayan anlaşmanın varlığına işaret eder (Davis,1984). İşletmeler sadece yazılı anlaşmayı esas alır, yazılı olmayan anlaşmayı göz ardı ederse, çalışanların örgütsel bağlılıkları ve işe ilişkin olumlu yaklaşımları azalır.

\section{İș Tatminini Etkileyen Faktörler}

Çalışanların iş tatmin düzeyleri ile ilgili geçmişte yapıllmış olan çalışmaların; amaç, zaman, yer (bölge, ülke vs.), sektör, araştırmanın gerçekleştirildiği organizasyonun/ işletmenin faaliyet alanı vb. konularda farklılaştığı için iş tatmini etkileyen çok sayıda faktör belirlenmiştir. Örneğin; iş tatmini ile motivasyon arasındaki iliş̧kisi araştıran Herzberg ve diğerleri (1959), iş tatminini etkileyen beş faktörün başarı (Achievement), tanınma (Recognition), işin kendisi (Work Itself), sorumluluk (Responsibility) ve yükselme (advancement) olduğunu ifade etmişlerdir.

Bazı araştırmacılar, çalışanların memnuniyet düzeylerinin içsel ve dışsal unsurlardan etkilendiğini öne sürmüşlerdir. Castillo ve Cano (2004), işgörenlerin sorumlu oldukları 
işte başarılı olmalarını ve bu şekilde kabul görmelerini, daha sonra yeni sorumluluklar almalarını ve örgüt hiyerarşisinde yükselme şansına sahip olmalarını çalışanların memnuniyet düzeyini olumlu etkileyen içsel unsurlar olarak sıralamışlardır. Diğer taraftan çalışanların iş ve arkadaş çevresi, aldıkları ücret, çalışma koşulları, yöneticilerin tutum ve davranışları ve örgütsel politikalar ise iş tatminini etkileyen dışsal unsurlar olarak belirtilmiştir.

Bowen (1980) ve Padilla-Velez (1993)'in çalışmalarından yararlanan Castillo ve Cano (2004, s.66), Herzberg'in hijyen ve motivasyon faktörlerini şu şekilde yeniden sıralamışlardır: Tanınma (Recognition), başarı (Achievement), yükselme olasılı̆̆ı (Possibility of Growth), ilerleme (advancement), ücret/maaş (salary), kişilerarası ilişkiler (Interpersonal Relations), yöneticiler (supervision), sorumluluk (Responsibility), politika ve yönetim (Policy and Administration), çalışma koşulları (Working Conditions) ve işin kendisi (Work Itself).

İş tatminini etkileyen faktörler arasında; kişisel özelikler (çalışan performansı, motivasyonu vb.), işletmenin genel durumu (çalşsan devir hızı, işletmenin büyüme hızı, verimliliği, başarısı vb.), işin niteliği, yönetim/yöneticilerin tutum ve davranışları, elde edilen çıkarlar, ek imkânlar, kararlara katılım, iş yerindeki iletişim süreci ve insani ilişkiler, kişisel gelişime sağlanan imkânlar, iş ortamı, mevcut uygulamalar vb. siralanabilir (Sabuncuoğlu vd., 2016, s.38; Örücü ve Esenkal, 2005, s.145).

Çalışanların iş tatminini etkileyen unsurları bireysel ve örgütsel faktörler olarak gruplandırmak da mümkündür (Spector, 1997; Sabuncuoğlu ve Tüz, 2005, s.38). Bireysel faktörler; genetik yatkınlık, aile kültürü, sosyo-kültürel ve eğitsel faktörler, değer yargıları ve iş deneyimi, yaş, cinsiyet, medeni durum, eğitim düzeyi, mesleki konum ve kıdem, kişilik, zekâ, hizmet süresi ve benzeri etkenlerden oluşur (Akıncı, 2002, s.6; Schultz ve Schultz, 2005; Yelboğa, 2007). Örgütsel faktörler ise işin niteliği, yönetim tarzı ve denetim biçimi, güvenlik duygusu, iletişim, ücret, gelişme ve yükselme imkânları, rekabet, çalışma şartları, birlikte çalışan kişiler ve örgütsel ortam ile ilgilidir (Akınc1, 2002).

\section{İs Tatmininin Alt Boyutları}

İş tatmininin ölçümü için çok sayıda ölçek geliştirilmiştir. Spector (1985) tarafindan geliştirilen, ulusal ve uluslararası bilimsel araştırmada kullanılmış olan iş tatmin ölçeğinin geçerliliği ve güvenilirliği defalarca test edilmiştir. Spector (1997), geliştirdiği iş tatmin ölçeği (The Job Satisfaction Survey) ile çalışanların genel iş tatmin düzeylerini ve iş tatmininin dokuz alt boyutunu analiz etmiştir. Ölçek toplam 36 sorudan oluşmaktadır, iş tatmininin her bir alt boyutu dört soru ile araştırılmıştır.

Yelboğa (2009), Spector'un geliştirdiği iş tatmin ölçeğini Türkçe'ye uyarlamış ve ilgili analizleri (Temel Bileşenler, Faktör vs., geçerlilik, güvenilirlik vs.) de yaparak tamamlamıştır. Spector $(1985 ;$ 1997) tarafından geliştirilen, Yelboğa (2009) tarafından Türkçe'ye uyarlanan ve bu çalışmada veri toplamak amacıyla kullanılmış olan iş tatmin ölçeğinin dokuz alt boyut aşağıda açıklanmıştır.

Ücret (Pay): Çalışanın emeği karşıllı̆ında işletme/organizasyon tarafindan sağlanan ödeme (para, ekonomik imkânlar, sosyal katkılar, diğer olanaklar vb.) iş tatmininin 
sağlanmasında önemli bir etkendir (Davis, 2004, s.499; Eroğluer, 2011). Yapılan araştırmalar çalışanların iş tatmininin sağlanması için aldıkları ücretin tek başına yeterli olmadığını, alınan ücret diğer çalışanların ücretleri ile karşılaştırıldığında anlamlı sonuçlara ulaşıldığını ortaya koymuştur (Aşan ve Erenler, 2008, s.206).

İş görenler sadece aldıkları ücretin düşük olmasının yanında, benzeri işlerde çalışanların ücretlerinden daha az ücret aldıklarında tatminsizlik duyarlar (Ergeneli ve Eryiğit, 2001, s.167). Bu nedenle işgörenlerin diğer çalışanlarla uyumlu olarak eğitim durumu, iş deneyimi ve iş için sarf ettikleri çabalara uygun olarak ücretlendirilmeleri iş tatminlerini artıracaktır (Yelboğa, 2012, s.180).

Yükselme (Promotion): Çalışanların organizasyon/işletme içerisinde hiyerarşik basamaklarda ilerleme imkânına sahip olması, memnuniyetlerini artırır (Spector, 1997). İş gören başarılı çalışmaları sonucunda hiyerarşik yapıda daha üst bir makama/göreve gelebileceğini bilirse, iş tatmin düzeyi yükselir.

Yöneticiler/Yönetim (Supervision): Yöneticinin iş görenlere karşı tutum ve davranışları, çalışanların iş tatmin düzeylerini etkileyen önemli bir unsurdur Keleş (2007, s.260). Yöneticiler tarafından sergilenen davranışlar çalışanların beklentileri ile uyumsuz olduğunda, çalışanlar yaptıkları işleriyle ilgili tatminsizlik duygusu yaşayabilirler.

İlave (Ek) İmkânlar (Fringe Benefits): Parasal ve parasal olmayan (ulaşım, servis, yemek, kıyafet vb.) olanaklar, çalışanların iş tatmin düzeyini etkiler.

Muhtemel (Olası) Ödüller (Contingent Rewards): Çalışanların olumlu performansları nedeniyle elde edebilecekleri parasal veya parasal olmayan olası ödüller, iş tatmin düzeylerini pozitif şekilde etkilemektedir.

Çalışma Koşulları (İşleyiş Prosedürleri) (Operating Procedures/Conditions): İşlerin yapılışına ilişskin kural, politika ve koşullar (Spector, 1997, s.8), çalışanların iş tatmin düzeylerini olumlu veya olumsuz şekilde etkilemektedir.

İş Arkadaşları (Coworkers): Çalışanların iş arkadaşlarıyla ilişkileri, iş tatmin düzeylerini etkilemektedir.

İşin Kendisi (Nature of Work/ work itself ): Yapılan işin türü çalışanların tatmin düzeyini etkiler. İlgi çekici, hoşa giden, daha fazla sorumluluk üslenmeyi gerektiren vb. işler bazı çalışanların iş ve yaşam tatminlerini düzeyini artırırken, bazılarının hoşnutsuzluğunu neden olabilmektedir (Chacko, 1983). Diğer taraftan Irani ve Scherler (2002) işin kendisi ile çalışanların olumlu düşüncelere sahip olması arasında pozitif yönlü ilişki olduğunu tespit etmişlerdir.

İletişim (Communicatin): İşletme (organizasyon) içerisindeki iletişim (Örn. ast-üst arasında ve çalışanlar arasında gerçekleşen iletişim), işgörenlerin iş tatmini düzeyini artırır veya azaltabilir. 


\section{YÖNTEM}

Çalışma kapsamında verilerin temin edilmesi için nicel yöntem kullanılmış ve Ankara'da faaliyet gösteren havacılık bakım merkezlerinde çalışan iş görenlere anket uygulanmıştır. Toplanan veriler istatistiki yöntemlerle irdelenmiş; bu kapsamda söz konusu bakım merkezlerindeki çalışanların iş tatmini düzeyleri, iş tatmini ile alt boyutları arasındaki ilişkiler ve demografik faktörlerin iş tatminine ve alt boyutlarına etkileri incelenerek analiz edilmiştir.

Çalışma için oluşturulan araştırma soruları "Havacılık bakım merkezlerinde çalışanlarııın iş tatmin düzeyleri nasıldır? Çalışanların demografik özellikleri çalışanların iş tatmini ve iş tatmininin alt boyutlarını nasıl etkilemektedir?" şeklinde ifade edilmiştir.

Araştırmada; iş tatmini ile iş tatmininin alt boyutları olan ücret, yükselme-kariyer, sosyal haklar, arkadaşlar, ödül, idare usulleri, iletișim, yönetici davranış̧ları ve çalışanların demografik özelliklerinin ilişkili olabileceği varsayılmış, uygulamada da bu varsayımın doğruluğu analiz edilmiştir.

Araştırmanın örneklem grubunun evreni temsil edebilecek nitelikte olduğu, katılımcıların anket sorularını doğru anladıkları ve içtenlikle doğru cevapladıkları varsayılmıştır. Kullanılan istatistiksel tekniklerin ve yapılan analizlerin araştırmanın amacına uygun olduğu değerlendirilmiş ve aşağıdaki hipotezler oluşturulmuştur:

H1: Havacılık bakım merkezlerinde çalışanların iş tatmin düzeyleri yüksektir.

$\mathrm{H} 2$ : Çalışanların iş tatmini düzeyi demografik özelliklerine (cinsiyete, medeni duruma, eğitim durumuna, unvana, toplam çalışma süresine) göre farklılaşmaktadır.

H2a: Çalışanların iş tatmini düzeyi cinsiyete göre farklılaşmaktadır.

$\mathrm{H} 2 \mathrm{~b}$ : Çalışanların iş tatmini düzeyi medeni durumlarına göre farklılaşmaktadır.

H2c: Çalışanların iş tatmini düzeyi eğitim durumlarına göre farklılaşmaktadır.

H2d: Çalışanların iş tatmini düzeyi unvanlarına göre farklılaşmaktadır.

H2e: Çalışanların iş tatmini düzeyi toplam çalışma sürelerine göre farklılaşmaktadır.

H3: Çalışanların iş tatmininin alt boyutlarına ilişkin algıları demografik özelliklerine (cinsiyete, medeni duruma) göre farklılaşmaktadır.

H3a: Çalışanların iş tatmininin alt boyutlarına ilişkin algıları cinsiyete göre farklılaşmaktadır.

H3b: Çalışanların iş tatmininin alt boyutlarına ilişkin algıları medeni durumlarına göre farklılaşmaktadır.

Araştırmanın sonuçları sadece Ankara'da faaliyet gösteren havacılık bakım merkezlerinde çalışanlar için geçerlidir. Sonuçlar Türkiye genelindeki havacılık bakım merkezlerine iliş̧in yapılacak çalışmalarda da değerlendirilebilir. Ancak bulguların 
Ankara dışındaki havacılık bakım merkezleri için genelleştirilmesi uygun değildir. Çalışma kapsamında yapılan değerlendirmeler, ankete katılanların sorulara verdiği cevaplar dikkate alınarak yorumlanmıştır. Bu nedenle söz konusu yorumlar ankete katılanların düşünceleri, değer yargıları ve fikirleri için geçerlidir.

Araştırmanın evrenini, Ankara'da faaliyet gösteren havacılık bakım merkezlerinde çalışan 1730 personel oluşturmaktadır. Örneklem büyüklüğü ise aşağıda gösterilen formül doğrultusunda hesaplanmıştır (Bal, 2001: 113-114). Formüle göre \%95 güven aralığında ana kitleyi (evreni) temsil etme kabiliyeti olan örneklem büyüklüğü 314 olarak hesaplanmıştır.

$\mathrm{n}=\frac{N * p * q * Z^{2}}{\left[(N-1) * t^{2}\right]+\left(p * q * Z^{2}\right)}$

$\mathrm{n}=\frac{1730 * 0.5 * 0.5 * 1.96^{2}}{\left[(1730-1) * 005^{2}\right]+\left(0.5 * 0.5 * 1.96^{2}\right)}=\frac{1661,5}{5.3}=314$ (değer yukarı yuvarlanmıştır)

Formülde kodlanan harflerin (n, N, t, p, q, Z) açıklamaları şu şekildedir;

n: Örneklem büyüklüğü,

$\mathrm{N}$ :Evren büyüklüğü,

t: Göz yumulabilir yanılgı $(\mathrm{p}<0.05)$,

p: İncelenen olayın gerçekleşme olasılığ 10,50 olarak alınmıştır),

q: İncelenen olayın gerçekleşmeme olasılı̆̆ (1-p),

$Z$ : Güven düzeyine göre standart değer (normal dağılım \%95 için 1.96).

Araştırma verileri, Ankara'daki beş adet havacılık bakım merkezinin farklı kademelerinde çalş̧an ve kolayda örnekleme yöntemiyle seçilmiş olan personele, OcakŞubat 2019 döneminde uygulanan anket çalışmasıyla toplanmıştır.

Örneklemin ana kütleyi iyi temsil etmesi gerektiği göz önünde bulundurulmuş, bu kapsamda mümkün olduğunca farklı sosyo-kültürel ve sosyoekonomik özellikleri olan iş görenlere ulaşılmaya çalışılmıştır. Katılımcılara dağıtılanlardan 400 adet anket formundan, geri dönen toplam 333 adet anketin araştırma kapsamında incelenebilecek nitelikte olduğu belirlenmiştir.

Veri toplamak amacıyla; Spector (1985; 1997) geliştirdiği, Yelboğa (2009)'nın Türkçe'ye uyarladığı ve geçmişte Türkiye'de yapılmış çalışmalarda (Aydemir, 2013; Koç ve Titiz, 2016; Erbay ve Arslan, 2017) da kullanılmış olan İş Tatmin Ölçeği (Job Satisfaction Scale-JSS)nden yararlanılmıştır. Anket formunda; birinci bölümde katılımcıların demografik özelliklerini belirlemeye yönelik 7 soru, ikinci bölümde ise iş tatmini ve alt boyutlarına ilişkin 36 soru olmak üzere toplam 43 adet soru yer almıştır. Sorular hazırlanırken 5'li Likert Tipi ölçek kullanılmıştır. Anket sonuçları SPSS 22 paket programı kullanılarak analiz edilmiştir. 


\section{BULGULAR VE TARTIŞMA}

Araştırmada kullanılan veriler, Cronbach Alfa katsayısına göre değerlendirilmiş ve "İş Tatmini” değişkeni (alfa $(\alpha)=0,834)$ toplam 36 soru ile incelenmiştir. Bu kapsamda iş tatmininin alt boyutlarından "ücret" değişkeni $(\alpha=0.827) 4$ soru, "yükselme-kariyer" $(\alpha=0.821) 4$ soru, "sosyal haklar" $(\alpha=0.817) 4$ soru, "çalışma/iş arkadaşları" $(\alpha=0.826)$ 3 soru, "ödül” ( $\alpha=0.852) 4$ soru, "işin doğası" $(\alpha=0.828) 7$ soru, "yönetim şekli/idare usulleri” ( $\alpha=0.820) 3$ soru, "iletişim" ( $\alpha=0.839) 3$ soru ve "yönetici davranışları" değişkeni ise $(\alpha=0.820)$ toplam 4 soru ile araştırılmıştır (Tablo 1).

Anketin soruları arasındaki ilişkilere işaret eden iç tutarlılık değeri, kabul edilebilir değer olan $(\alpha=0.70)$ 'ten yüksektir (Bayram, 2004, s.127; Gürbüz ve Şahin, 2016, s.323). Kalaycı (2009) tarafindan belirtilen güvenilirliğe ilişkin değer aralıkları dikkate alındığında da, araştırmada kullanılan ölçeğin yüksek derecede güvenirliğe sahip olduğu anlaşılmaktadır. Araştırmada elde edilen verilerin güvenilirlik analizi tamamlandıktan sonra, veri toplamak amacıyla kullanılan ölçeğin alt boyutlarına ilişkin Skewness ve Kurtosis çarpıklık değerleri kontrol edilmiş, "+1 ile -1 ” arasında kalan değerlerden çalışma verilerinin normal dağılım gösterdiği anlaşılmıştır.

Ankete katılanlarla ilgili demografik bilgiler incelendiğinde, büyük çoğunluğunun genç sayılabilecek 30-50 yaş arasında olduğu görülmektedir (\%0,6'sl 21-25 yaş, \%14,1'i 26-30 yaş, \%16,5'i 31-35 yaş, \%18,9'u 36-40 yaş, \%30'u 41-45 yaş, \%19,8'i ise 46 ve daha büyük yaştadır). Bu kapsamda çalışanların \%13,5'si kadın (45 personel), \%86,5'i erkek (286 personel), \%86,2'si evli (287 personel) ve \%13,8'i bekârdır (evlenmemiş, eşinden ayrılmış veya eşi vefat etmiş olanlar da dâhildir).

Katılımcıların eğitim durumu incelendiğinde; \%0,3 ilkokul, \%4,5 ortaokul, \%19 lise, $\% 16,8$ yüksekokul, $\% 40,2$ lisans, $\% 18,9$ yüksek lisans ve $\% 0,3$ oranında doktora eğitimi almış iş gören olduğu ortaya çıkmıştır. Sonuçlardan da anlaşıldı̆̆ı şekilde; hava araçlarının bakımı için teknik hizmet sağlayan ve altyapı gerektiren Bakım Merkezlerindeki iş görenlerin önemli bir kısmı (yaklaşık \%80) ön lisans, lisans ve lisansüstü eğitim almışlardır.

Araştırma için görüşleri alınan iş görenlerden \%4,5'i şef, \%26,4'ü mühendis, \%64,3'ü teknik personel ve $\% 4,8$ 'i idari personel kadrolarında görev yapmaktadır. Değerlendirmeye dâhil edilen anketleri dolduranların görevleri incelendiğinde, Hava Araçları Bakım Merkezlerindeki çalışların çoğunluğunun (yaklaşık \%90) mühendis, teknisyen vb. teknik personelden oluştuğu dikkat çekmektedir.

Katılımcıların çalışma süreleri incelendiğinde, aynı iş yerinde 5 yıldan uzun süredir çalışanların \%90 civarında olduğu anlaşılmaktadır (\%9'u 1-5 yll; \%7,2'si 6-10 yll; \%10,5'i 11-15 yll; \%18,9'u 16-20 yll; \%29,3'ü 21-25 yll; \% 24,9'u 26 yll ve üzerinde çalı̧̧ma süresi). Bu kapsamda söz konusu personelin iş tatmini ve iş tatmini etkileyen demografik faktörlerle ilgili değerlendirme yapıp görüş bildirecek birikime sahip olduğu söylenebilir. Diğer taraftan, iş görenlerin mevcut iş yerindeki çalışma süreleri incelendiğinde, 6-10 yıl süreyle aynı işletmede çalışan personelin (\%56) en büyük grubu oluşturduğu görülmektedir (1-5 yll: \%14,7; 11-15 yll: \%8,4; 16-20 yll: \%5,1; 21 25 yıl: \%9,6; 26 yıl ve üzeri: \%6). 
Ankete katılanların örgütsel yapı (teşkilat) içindeki görevleri ve mesleki deneyimi genel olarak değerlendirildiğinde; söz konusu Havacılık Bakım Merkezlerinde ișini iyi bilen, ehil, konusunda uzmanlaşmış profesyonel personelin istihdam edildiği ve bu iş görenlerin kaliteli hizmet sağlayabileceği söylenebilir.

Çalışmada daha sonra iş tatmini ve iş tatmininin alt boyutları olan değişkenlere ilişkin ortalamalar tespit edilmiştir (Tablo 1). Değişkenlere ait ortalama değerlerin genellikle kararsılılı düzeyinde olduğu ortaya çıkmıştır. (Ölçekte yer alan değişkenlere ait soruların ortalamaları da incelemeye dâhil edilmiş, yine aynı sonuçlar gözlemlenmiştir).

Değişkenlerin ortalama değerlerin incelendiğinde; genel olarak çalışanların iş tatmin düzeyleri ile iş tatmininin alt boyutlarından olan "ücret, ödül ve arkadaşlar" değişkenlerine ilişkin değerlerin ortalamanın üzerinde olduğu belirlenmiştir. Başka bir deyişle; çalışanların genel olarak iş tatmin düzeylerinin yüksek (iyi) olduğu, ayrıca "ücret, ödül ve arkadaşlar” açısından iş görenlerin memnun oldukları söylenebilir. İş tatmininin diğer alt boyutları (yükselme-kariyer, sosyal haklar, işin doğası, idare usulleri, iletişim ve yönetici davranışları) açısından çalışanların tatmin olma durumunun gerçekleşmediği (tatmin olmadıkları) ifade edilebilir. Bu sonuçlara göre H1 hipotezi (Havacılık bakım merkezlerinde çalışanların iş tatmin düzeyleri yüksektir.) kabul edilmiştir.

Tablo 1: Değişkenlerin Güvenilirlik Analizleri, Ortalama ve Standart Sapma Değerleri

\begin{tabular}{|l|c|c|c|c|c|c|}
\hline $\begin{array}{c}\text { Ölçek ve Alt } \\
\text { Boyutları }\end{array}$ & $\begin{array}{c}\text { Cronbach's } \\
\text { Alpha }(\alpha)\end{array}$ & $\begin{array}{c}\text { Soru } \\
\text { Numaras1 }\end{array}$ & $\begin{array}{c}\text { Soru } \\
\text { Sayısı }\end{array}$ & $\mathrm{N}$ & Ortalama & $\begin{array}{c}\text { Standart } \\
\text { Sapma }\end{array}$ \\
\hline İş Tatmini & 0,834 & $\begin{array}{c}36 \text { sorunun } \\
\text { tamamı }\end{array}$ & 36 & 333 & 3,0138 & 0,3816 \\
\hline -Ücret & 0.827 & $1-10-19-28$ & 4 & 333 & 3,2613 & 0,5684 \\
\hline -Ödül & 0.852 & $5-21-23-32$ & 4 & 333 & 3,1351 & 0,5715 \\
\hline $\begin{array}{l}\text {-Yükselme- } \\
\text { Kariyer }\end{array}$ & 0.821 & $2-11-20-33$ & 4 & 333 & 2,7357 & 0,5949 \\
\hline -Sosyal Haklar & 0.817 & $4-13-22-29$ & 4 & 333 & 2,8821 & 0,6079 \\
\hline -Arkadaşlar & 0.826 & $7-16-25$ & 3 & 333 & 3,2222 & 0,6550 \\
\hline -̇̇sin doğası & 0,828 & $\begin{array}{c}6-8-14-17- \\
24-27-35\end{array}$ & 7 & 333 & 3,0108 & 0,5817 \\
\hline -İdare Usulleri & 0.820 & $15-31-36$ & 3 & 333 & 2,9630 & 0,6649 \\
\hline -̇̇letişim & 0.839 & $9-18-26$ & 3 & 333 & 2,7497 & 0,5861 \\
\hline $\begin{array}{l}\text {-Yönetici } \\
\text { Davranışları }\end{array}$ & 0.820 & $3-12-30-34$ & 4 & 333 & 2,9197 & 0,5668 \\
\hline
\end{tabular}

Çalışanların demografik özellikleri ile iş tatmini (ve iş tatmininin alt boyutları) arasındaki ilişkileri analiz etmek amacıyla, "t" testi ve "one-way anova" testi kullanılmıştır. Başka bir deyişle; iki bağımsız değişkenin örneklem ortalamaları arasında istatistiksel açıdan fark olup olmadığını tespit etmek için " $t$ " testi, ikiden fazla bağımsız değişkenin örneklem ortalamaları arasındaki farkın istatistiksel olarak anlamlı 
olup olmadığını ve değişkenler arası farklılığın hangi değişkenden kaynakladığını belirlemek için “one-way anova” testi kullanılmıştır (Çoşkun vd., 2015 s. 182-199).

Cinsiyete göre grup farklılıkları t-testi ile değerlendirildiğinde; bir bütün olarak "iş tatmini" ile iş tatmininin alt boyutlarından "yükselme-kariyer ve iletişim" değişkenlerinin örneklem ortalamaları arasında istatistiksel olarak anlamlı $(p<0,05)$ farklılıklar olduğu tespit edilmiştir (Tablo 2).

Tablo 2: Cinsiyet Açısından İş Tatmin Düzeyi t Testi

\begin{tabular}{|c|c|c|c|c|c|c|c|}
\hline & Cinsiyet & $\mathrm{N}$ & $\mathrm{X}$ & SS & $\mathrm{F}$ & $\mathrm{P}$ & $\mathrm{t}$ \\
\hline \multirow{2}{*}{$\begin{array}{l}\text { Yükselme } \\
\text {-Kariyer }\end{array}$} & Kadın & 45 & 2,5833 & ,75754 & \multirow{2}{*}{13,416} & \multirow{2}{*}{,000 } & \multirow{2}{*}{$-1,855$} \\
\hline & Erkek & 288 & 2,7595 & ,56320 & & & \\
\hline \multirow{2}{*}{ İletişim } & Kadın & 45 & 2,8519 & ,78030 & \multirow{2}{*}{17,368} & \multirow{2}{*}{,000 } & \multirow{2}{*}{1,258} \\
\hline & Erkek & 288 & 2,7338 & ,54963 & & & \\
\hline \multirow{2}{*}{ İş Tatmini } & Kadın & 45 & 2,9877 & ,50498 & \multirow{2}{*}{3,905} & \multirow{2}{*}{,049 } & \multirow{2}{*}{,- 493} \\
\hline & Erkek & 288 & 3,0178 & ,35954 & & & \\
\hline
\end{tabular}

Başka bir deyişle, kadın ve erkek çalışanların; genel olarak iş tatmini, iletişim ve kariyer-yükselme algılarının farklı olduğu söylenebilir. Bu durumda $\mathrm{H} 2 \mathrm{a}$ hipotezi (Çalışanların iş tatmini düzeyi cinsiyete göre farklılaşmaktadır.) kabul edilmiştir. H3a hipotezi (Çalı̧̧anların iş tatmininin alt boyutlarına ilişkin algıları cinsiyete göre farklılaşmaktadır.) ise iş tatminin alt boyutlarından sadece "yükselme-kariyer ve iletişim” değişkenlerinde anlamlı farklılıklar oluştuğundan kısmen kabul edilmiştir.

Tablo 3: Medeni Durum Açısından İş Tatmin Düzeyi t Testi

\begin{tabular}{|c|c|c|c|c|c|c|c|}
\hline & $\begin{array}{l}\text { Medeni } \\
\text { Durum }\end{array}$ & $\mathrm{N}$ & $X$ & SS & $\mathrm{F}$ & $\mathrm{p}$ & $\mathrm{T}$ \\
\hline \multirow{2}{*}{$\begin{array}{l}\text { Yükselme- } \\
\text { Kariyer }\end{array}$} & Evli & 287 & 2,7770 & ,56323 & \multirow[t]{2}{*}{19,011} & \multirow{2}{*}{,000 } & \multirow{2}{*}{3,206} \\
\hline & Bekâr & 46 & 2,4783 & ,71846 & & & \\
\hline \multirow{2}{*}{ Sosyal Haklar } & Evli & 287 & 2,8990 &, 56274 & \multirow[t]{2}{*}{14,608} & \multirow{2}{*}{,000 } & \multirow{2}{*}{1,263} \\
\hline & Bekâr & 46 & 2,7772 & ,83704 & & & \\
\hline \multirow{2}{*}{ İletişim } & Evli & 287 & 2,7375 & ,55681 & \multirow[t]{2}{*}{11,958} & \multirow{2}{*}{, 001} & \multirow{2}{*}{,- 951} \\
\hline & Bekâr & 46 & 2,8261 & ,74615 & & & \\
\hline \multirow{2}{*}{ İş Tatmini } & Evli & 287 & 3,0278 & ,35625 & \multirow{2}{*}{7,443} & \multirow{2}{*}{, 007} & \multirow{2}{*}{1,678} \\
\hline & Bekâr & 46 & 2,9263 & ,50881 & & & \\
\hline
\end{tabular}

Çalışanların medeni durumuna göre grup farklılıkları incelendiğinde; bir bütün olarak "iş tatmini" ile iş tatmininin alt boyutlarından "yükselme-kariyer, sosyal haklar ve iletişim" değişkenlerinin örneklem ortalamaları arasında istatistiksel olarak anlamlı $(\mathrm{p}<0,05)$ farklılıklar olduğu ortaya çıkmıştır. (Tablo 3). Başka bir deyişle, evli ve bekâr çalışanların; genel olarak iş tatmini, iletişim, sosyal haklar ve kariyer-yükselme algılarının farklı olduğu söylenebilir. Bu durumda H2b hipotezi (Çalışanların iş tatmini düzeyi medeni durumlarına göre farklılaşmaktadır.) kabul edilmiştir. H3b hipotezi (Çalışanların iş tatmininin alt boyutlarına ilişkin algıları medeni durumlarına göre 
farklılaşmaktadır.) ise iş tatminin alt boyutlarından sadece "yükselme-kariyer, sosyal haklar ve iletişim" değişkenlerinde anlamlı farklılıklar oluştuğundan kısmen kabul edilmiştir.

Çalışanların eğitim durumuna göre grup farklılıkları incelendiğinde; bir bütün olarak "iş tatmini”" için istatistiksel olarak anlamlı $(\mathrm{p}<0,05)$ farklılıklar olduğu ortaya çıkmıştır. (Tablo 4). İlkokul, ortaokul ve doktora mezunu çalışanların tamamı, toplam çalışanlar içerisinde $\% 5$ 'ten daha az bir oranda bulunduğundan, söz konusu eğitim seviyesindeki çalışanların iş tatmin durumlarına ilişkin anlamlı farklılıklar oluşmamıştır.

Tablo 4: Eğitim Durumu Açısından İş Tatmininin Değerlendirilmesi

\begin{tabular}{|c|c|c|c|c|c|c|}
\hline \multicolumn{2}{|l|}{$\begin{array}{l}\text { Dependent } \\
\text { Variable }\end{array}$} & $\begin{array}{l}\text { (I) Eğitim } \\
\text { Durumu }\end{array}$ & $\begin{array}{l}\text { (J) Eğitim } \\
\text { Durumu }\end{array}$ & $\begin{array}{c}\text { Mean } \\
\text { Difference (I-J) }\end{array}$ & $\begin{array}{l}\text { Std. } \\
\text { Error }\end{array}$ & Sig. \\
\hline \multirow{6}{*}{ İş tatmini } & \multirow{6}{*}{$\begin{array}{l}\text { Tukey } \\
\text { HSD }\end{array}$} & Lise & Lisans & ,20578* &, 06395 & 012 \\
\hline & & Yüksekokul & Lisans & ,26983* & 06661 &, 001 \\
\hline & & Lisans & Lise &,$- 20578 *$ & 06395 & 012 \\
\hline & & & Yüksekokul &,$- 26983 *$ & ,06661 & 001 \\
\hline & & & Yüsek Lisans &,$- 29573 *$ & 06395 &, 000 \\
\hline & & Yüsek Lisans & Lisans & ,29573* &, 06395 &, 000 \\
\hline
\end{tabular}

Başka bir deyişle, lise, yüksekokul, lisans ve yüksek lisans mezunu çalışanların; genel olarak iş tatmini algılarının farklı olduğu söylenebilir. $\mathrm{Bu}$ durumda H2c hipotezi (Çalışanların iş tatmini düzeyi eğitim durumlarına göre farklılaşmaktadır.) kabul edilmiştir.

Tablo 5: Çalışanların Unvanı Açısından İş Tatmininin Değerlendirilmesi

\begin{tabular}{|l|lll|l|c|c|}
\hline $\begin{array}{l}\text { Dependent } \\
\text { Variable }\end{array}$ & (I) Unvan & (J) Unvan & $\begin{array}{c}\text { Mean } \\
\text { Difference (I-J) }\end{array}$ & $\begin{array}{c}\text { Std. } \\
\text { Error }\end{array}$ & Sig. \\
\hline \multirow{2}{*}{ İş tatmini } & $\begin{array}{l}\text { Tukey } \\
\text { HSD }\end{array}$ & Mühendis & $\begin{array}{l}\text { Teknik } \\
\text { personel }\end{array}$ &, $24683^{*}$ &, 05398 &, 000 \\
\cline { 3 - 7 } & & Teknik personel & Mühendis &,$- 24683^{*}$ &, 05398 &, 000 \\
\hline
\end{tabular}

Çalışanların unvanlarına göre grup farklılıkları incelendiğinde; bir bütün olarak "iş tatmini” için istatistiksel olarak anlamlı $(\mathrm{p}<0,05)$ farklılıklar olduğu ortaya çıkmıştır. (Tablo 5).

Toplam çalışanlar içerisinde \%5'ten daha az oranda bulunan şef ve idari personel konumundaki çalışanların iş tatmin durumlarına ilişkin anlamlı farklılıklar oluşmamıştır. Diğer taraftan Mühendis $(\% 26,4)$ ve teknik personel $(\% 64,3)$ arasındaki unvana bağlı negatif yönlü ilişkinin, benzer işler yapmalarına rağmen iş sonucunda farklı kazanımlar elde etmelerinden kaynaklanabileceği kıymetlendirilmektedir. Bu kapsamda teknik personelin ve mühendislerin iş tanımlarının yeniden gözden geçirilmesi yararlı olabilir. 
Sonuç olarak katılımcıların yaklaşık \%90’ını oluşturan teknik personel ve mühendislerin iş tatmin durumlarına ilişkin anlamlı farklılıklar tespit edildiğinden, $\mathrm{H} 2 \mathrm{~d}$ hipotezi (Çalışanların iş tatmini düzeyi unvanlarına göre farklılaşmaktadır.) kabul edilmiştir.

Çalışanların toplam çalışma sürelerine göre grup farklılıkları incelendiğinde; bir bütün olarak "iş tatmini" için istatistiksel olarak anlamlı $(\mathrm{p}<0,05)$ farklılıklar olduğu ortaya çıkmıştır. (Tablo 6). Toplam çalışma süresi en fazla olan grubun (\% 24,9'u 26 yll ve üzerinde çalışma süresi) iş tatminine ilişkin algılarının diğer grupların yaklaşı tamamından pozitif yönde yarıştığı dikkat çekmektedir. Bu nedenle toplam çalışma süresi artan çalışanların iş tatmin düzeylerinin de arttığ 1 söylenebilir. Diğer taraftan iş tatmin düzeyi daha düşük olan yaşları genç çalışanlarla yakından ilgilenmesinin olumlu sonuçlar doğuracağı söylenebilir.

Tablo 6: Toplam Çalışma Süresi Açısından İş Tatmininin Değerlendirilmesi

\begin{tabular}{|c|c|c|c|c|c|c|}
\hline $\begin{array}{l}\text { Dependent } \\
\text { Variable }\end{array}$ & & $\begin{array}{l}\text { (I) Toplam } \\
\text { Çalışma } \\
\text { Süresi (yıl) }\end{array}$ & $\begin{array}{c}\text { (J) Toplam } \\
\text { Çalışma Süresi } \\
(y 11)\end{array}$ & $\begin{array}{c}\text { Mean } \\
\text { Difference (I-J) }\end{array}$ & $\begin{array}{l}\text { Std. } \\
\text { Error }\end{array}$ & Sig. \\
\hline \multirow{10}{*}{ İş tatmini } & \multirow{10}{*}{$\begin{array}{l}\text { Tukey } \\
\text { HSD }\end{array}$} & $6-10$ & 26 yil ve ustu &,$- 47462^{*}$ & ,09464 &, 000 \\
\hline & & $11-15$ & 26 yil ve ustu &,$- 30227^{*}$ &, 08230 &, 004 \\
\hline & & \multirow[t]{2}{*}{$16-20$} & $21-25$ &,$- 19148^{*}$ & ,06594 &, 045 \\
\hline & & & 26 y1l ve ustu &,$- 45191^{*}$ &, 06824 &, 000 \\
\hline & & \multirow[t]{2}{*}{$21-25$} & $16-20$ &, $19148^{*}$ & ,06594 &, 045 \\
\hline & & & 26 y1l ve ustu &,$- 26043^{*}$ & ,06092 &, 000 \\
\hline & & \multirow[t]{4}{*}{26 y1l ve ustu } & $6-10$ &, $47462^{*}$ & ,09464 &, 000 \\
\hline & & & $11-15$ &, $30227^{*}$ &, 08230 &, 004 \\
\hline & & & $16-20$ &, $45191^{*}$ &, 06824 &, 000 \\
\hline & & & $21-25$ &, $26043^{*}$ & ,06092 & ,000 \\
\hline
\end{tabular}

$\mathrm{Bu}$ durumda $\mathrm{H} 2 \mathrm{e}$ hipotezi (Çalışanların iş tatmini düzeyi toplam çalışma sürelerine göre farklılaşmaktadır.) kabul edilmiştir.

\section{SONUÇ VE ÖNERILER}

Çalışanların iş tatmini, etkin bir insan kaynakları planlaması ve yönetimi sonucunda ortaya çıkar. Organizasyondaki sorunların tespiti açısından iş görenlerin iş tatmini düzeylerinin düşmesi, önemli bir göstergedir. İş tatmini etkileyen faktörlerden demografik değişkenler dikkat çekici olduğundan, değişkenlerden kaynaklanan farklılaşmaları irdeleyen çok sayıda araştırma yapılmıştır (Arslan ve Demir, 2017; Soysal vd., 2017; Karaman, 2018).

Araştırmalardan edilen bulgular çalışanların iş tatmin düzeylerinin; yaş, cinsiyet, medeni durum, eğitim durumu, meslek, iş yeri deneyimi, mesleki deneyim, statü/unvan vb. değişkenlere bağlı olarak farklılaştığını ortaya koymuştur. (Koç veTitiz, 2016; Aksu, 2012; Bilgiç, 1998; Pınar vd., 2008; Yıldız vd., 2003). Örneğin Bilgiç (1998), 
çalışanların evli olup olmamaları ile iş tatmini düzeyleri arasında herhangi bir ilişkiye rastlamamıştır. Dolayısıyla konuya ilişkin yeni çalışmaların yapılmasının yararlı olacağı düşünülmektedir.

Ticari hava taşımacılığında kullanılan sivil ve resmi her türlü hava aracına bakım ve onarım hizmeti sağlayan havacılık bakım merkezlerindeki çalışanların iş tatmini, hizmet kalitesi açısından hayati öneme sahiptir. Hizmet üreten benzeri örgütlerde çalışanların iş tatmin düzeylerinin izlenmesine ve iyileştirilmesine ihtiyaç vardır. Bu araştırmada; havacılık bakım merkezlerindeki çalışanların iş tatmini düzeylerini araştırmak, iş tatmini ile alt boyutları arasındaki ilişkileri incelemek ve demografik faktörlerin iş tatminine ve alt boyutlarına etkilerini analiz etmek amaçlanmıştır.

Araştırma sonucunda demografik değişkenlerden cinsiyet, medeni durum, eğitim durumu, toplam çalışma süresi ve unvan farklılıklarının çalışanların tatmin düzeyini önemli ölçüde etkilediği tespit edilmiştir. Özellikle kadın ve erkek çalışanların iş tatmininin alt boyutlarından "iletişim ve kariyer-yükselme" ile ilgili algılarının farklı olduğu ortaya çıkmıştır. Diğer taraftan evli ve bekâr çalışanların "iletişim, sosyal haklar ve kariyer-yükselme" şeklindeki iş tatmininin alt boyutlarına ilişkin algılarında farklılıklar olduğu belirlenmiştir.

Lisans mezunu çalışanların $(\% 40)$ iş tatmin seviyelerindeki farklılık dikkat çekicidir; nedenlerinin araştırılması, irdelenmesi ve iyileştirme önlemlerinin alınması gerektiği düşünülmektedir. Mühendis $(\% 26,4)$ ve teknik personel $(\% 64,3)$ arasındaki unvana bağlı negatif ilişkinin, benzeri işleri yaparken farklı kazanımlar elde etmelerinden kaynaklandığı kıymetlendirilmektedir. Bu kapsamda teknik personelin ve mühendislerin iş tanımlarının yeniden gözden geçirilmesi yararlı olabilir.

Araştırma sonuçlarına göre çalışanların toplam çalışma süresi ve aynı iş yerinde çalışma süresi arttıkça, çevreye ve yaptıkları işlere uyumlarının arttı̆̆ taraftan iş tatmin düzeyi daha düşük olan genç çalışanlarla yakından ilgilenmesinin ve iş tatminlerini arttırıcı önlemler geliştirilip uygulanmasının yararlı olacağ değerlendirilmektedir.

\section{KAYNAKÇA}

Akıncı, Z. (2002), Turizm Sektöründe İşgören İş Tatminini Etkileyen Faktörler: Beş Yıldızlı Konaklama İşletmelerinde Bir Uygulama, Akdeniz İktisadi ve İdari Bilimler Fakültesi Dergisi, Sayı: 4. s.1-25.

Aksu, N. (2012). İş Tatmininin Bazı Demografik Değişkenler Açısından İncelenmesi. Polis Bilimleri Dergisi. 14. (1):59-79.

Armstrong, M. (2006). A Handbook of Human Resource Management Practice, Tenth Edition, Kogan Page Publishers 
Arslan, E.T., Demir, H. (2017). "İșe Angaje Olma ve İş Tatmini Arasındaki İlişki: Hekim ve Hemşireler Üzerine Nicel Bir Araştırma”. Yönetim ve Ekonomi. C.24 (2): 371-389.

Aşan, Ö., Erenler, E. (2008). İş Tatmini ve Yaşam Tatmini İlişkisi. Süleyman Demirel Üniversitesi İktisadi ve İdari Bilimler Fakültesi Dergisi, 13 (2): 203-216.

Aydemir P., Erdoğan E. (2013), İş Görenlerin Ücret Tatmini, İş Tatmini ve Performans Algısı, Kamu İş; Cilt:13,Sayı:2, s.127-153

Aziri, B. (2011). Job Satisfaction: A Literature Review. Management Research and Practice, 3 (4), 77-86.

Bakan, İ., Büyükbeşe, T. (2011). Örgütsel İletişim ve İş Tatmini Unsurları Arasındaki İlişkiler: Akademik Örgütler İçin Bir Alan Araştırması. Akdeniz Üniversitesi İktisadi ve İdari Bilimler Fakültesi Dergisi (7), 1-30.

Bal, H. (2001). Bilimsel Araştırma Yöntem ve Teknikleri. Süleyman Demirel Üniversitesi Basımevi, Yayın No: 20, Isparta.

Bayram, N. (2004). Sosyal Bilimlerde SPSS ile Veri Analizi. Bursa, Ezgi Kitabevi.

Berry, L.M. (1997). Psychology at Work: An Introduction to Industrial and Organizational Psychology, Mc. Graw Hill Companies Inc. San Francisko

Bilgiç, R. (1998). The Relationship Between Job Satisfaction And Personal Characteristics Of Turkish Workers. Journal of Psychology, 132 (5): 549-558.

Bowen, B. E. (1980). Job Satisfaction of Teacher Educators in Agriculture. Unpublished doctoral dissertation, The Ohio State University, Columbus.

Castillo, J. X., Cano J., (2004). Factors Explaining Job Satisfaction Among Faculty, Journal of Agricultural Education. Vol.45. Number 3: 65-74, DOI: $10.5032 /$ jae. 2004.03065

Chacko, T. I. (1983). Job and life satisfactions: A causal analysis of their relationships. Academy of Management Journal, Vol.26 (1): 163-169.

Coşkun, R., Altunışık, R., Bayraktaroğlu, S., Yıldırım, E. (2015). Sosyal Bilimlerde Araştırma Yöntemleri SPSS Uygulamalı, Serkan Yayıncılık 8.Baskı, Sakarya.

Davis, G. (2004). Job Satisfaction Survey Among Employees in Small Business, Journal of Small Business and Enterprise Development, 11 (4): 495-503.

Davis, K. (1984), (Çev. Kemal Tosun ve diğerleri), İşletmede İnsan Davranış1- Örgütsel Davranış, İstanbul Üni. İşletme Fak. Yayınları, Yayın No:136, İstanbul

Erbay, E., Aslan, E. (2017). Ankara Aile ve Sosyal Politikalar İl Müdürlüğüne Bağlı Çocuk Evlerinde Çalışan Bakım Elemanları ve Çocuk Evi Sorumlularının İş Doyumu ve Tükenmişlik Düzeyleri. Türkiye Sosyal Araştırmalar Dergisi, (2), s.535-556. 
Erdil, O., Keskin, H., İmamoğlu, S. Z., Erat,S. (2004). Yönetim Tarzı ve Çalışma Koşulları Arkadaşlık Ortamı ve Takdir Edilme Duygusu ile İş Tatmini Arasındaki İlişkiler: Tekstil Sektöründe Bir Uygulama. Doğuş Üniversitesi Dergisi, Cilt 5, Sayı 1: 17- 26.

Erdoğan, İ. (1996), İşletme Yönetiminde Örgütsel Davranış. İstanbul Üniversitesi İşletme Fakültesi Yayınları, Yayın No: 266/158.

Ergeneli, A., Eryiğit, M. (2001). Öğretim Elemanlarının İş Tatmini: Ankara'da Devlet ve Özel Üniversite Karşılaştırması. Hacettepe Üniversitesi İktisadi ve İdari Bilimler Fakültesi Dergisi, 19 (2), 159-178.

Eroğluer, K. (2011), Örgütsel İletişim ile İş Tatmini Unsurları Arasındaki İlişkiler: Kuramsal Bir İnceleme, Ege Akademik Bakış, 11 (1): 121-136.

Ertürk, E., Keçecioğlu, T. (2012), Çalışanların İş Doyumları ile Mesleki Tükenmişlik Düzeyleri Arasındaki İlişkiler: Öğretmenler Üzerine Örnek Bir Uygulama, Ege Akademik Bakış, C. 12, S.1, s.39-52.

Gürbüz, S., Şahin, F. (2016). Sosyal Bilimlerde Araştırma Yöntemleri Felsefe-YöntemAnaliz, (Gözden geçirilmiş ve Güncellenmiş 3. Baskı). Ankara: Seçkin Yayıncilık.

Herzberg, F., Mausner, B., Snyderman, B. B. (1959). The Motivation to Mork. New York: John Wiley \& Sons.

Irani, T., Scherler, C. (2002), Job Satisfaction as an Outcome Measure of the Effectiveness of an Agricultural Communications Academic Program, Journal of Agricultural Education, 43 (1): 12-23 DOI: 10.5032/jae.2002.01012

Kalaycı, Ş. (2009), SPSS Uygulamalı Çok Değişkenli İstatistik Teknikleri, Asil Yayın Dağıtım, Ankara

Karaman, D. (2018). Demografik Özelliklerin İş Tatmini Üzerindeki Etkisi: Eğitim Sektöründe Bir Uygulama. Kırklareli Üniversitesi Sosyal Bilimler Dergisi, 2 (1), 65-78.

Keleş, H.N. (2007), İş Tatmininin Örgütsel Bağlılık Üzerindeki Etkisine İlişkin İlaç Üretim ve Dağıtım Firmalarında Yapılan Bir Araştırma, Sosyal Ekonomik Araştırmalar Dergisi, 7 (13): 243-263

Koç, M., Titiz, H. (2016). Kadın Yöneticilerde İş Tatmin Düzeylerinin Orta Yetişkinlik Dönemi Açısından İncelenmesi. Sosyal Bilimler Araştırmaları Dergisi, (15) : 331-364.

Locke, E. A. (1969), What is Job Satisfaction. Organizational Behavior and Human Performance, Vol:4: 309-336.

Locke, E.A. (1983) The Nature and Causes of Job Satisfaction. In: Dunnette, M.D., Ed., Handbook of Industrial Psychology, Rand-McNally College Publishing Company, Chicago, 1297-1349 
Luthans, F., (1995). Organizational Behavior. McGraw-Hill, Inc., New York, USA

Mercer, D. (1997), Job Satisfaction and the Secondary Headteacher: The Creation of a Model of Job Satisfaction, School Leadership and Management. V. 17, N. 1: 57 68

Muchinsky, P. M. (2006). Psychology Applied to Work: An Introduction to Industrial and Organizational Psychology. Cengage Learning.

Oshagbemi, T. (1997). The Influence of Rank on the Job Satisfaction in Higher Education. Education and Training, 39, 354-359 as cited in Schulze, S. (2006). Factors Influencing the Job Satisfaction of Academics in Higher Education. SAJHE, 20(2), 318-335.

Örücü, E., Esenkal, F. (2005). "Konaklama İletmelerinde İş Gören Tatminini Etkileyen Faktörler (Bandırma ve Erdek Örneği)", Balıkesir Üniversitesi SBE Dergisi, Vol:8, No:14, s:141-166.

Özdevecioğlu, M. (2004). Algılanan Örgütsel Desteğin İşten Ayrılma Niyeti Üzerindeki Etkileri. Türkiye ve Ortadoğu Amme İdare Enstitüsü Dergisi, 37 (4): 97-115.

Padilla-Velez, D. (1993). Job satisfaction of Vocational Teachers in Puerto Rico. Unpublished doctoral dissertation, The Ohio State University, Columbus.

Pekdemir, İ., Özçelik, O., Karabulut, E., Arslantaş, C.C. (2006). Personel Güçlendirme, İş Tatmini ve Örgütsel Bağlılık Arasındaki İlişkileri Belirlemeye Yönelik Bir Çalışma, Verimlilik Dergisi, 2006/4: 12-36.

Pınar, İ., Kamaşak, R., Bulutlar, F. (2008); İş Tatmini Oluşturan Boyutların Toplam Tatmin Üzerindeki Etkilerinin Doğrulayıcı Faktör Analizi ile İncelenmesi Üzerine Türk İşletmelerinde Bir Araştırma, İstanbul Üniversitesi İşletme Fakültesi Dergisi, 37 (2): 151-166.

Pierchy, N.F., (1998). "Barriers to Implementing Relationship Marketing: Analysing the Internal Market-Place”. Journal of Strategic Marketing, Vol.6: 209-228.

Poyraz, K., Kama, B., (2008). Algılanan İş Güvencesinin, İş Tatmini, Örgütsel Bağlılık ve İşten Ayrılma Niyeti Üzerindeki Etkilerinin İncelenmesi. Süleyman Demirel Üniversitesi İktisadi ve İdari Bilimler Fakültesi Dergisi, C.13 (2):143-164.

Sabuncuoğlu, Z., Tüz, M. (2005), Örgütsel Psikoloji, Alfa Aktüel Basım Yayın, Bursa, s.62.

Sabuncuoğlu, Z., Vergiliel, Tüz, M. (2016). Örgütsel Davranış, (6. Baskı), Bursa: Aktüel Yayıncılık

Schultz, D.P., Schultz, S.E. (2005) Psychology And İndustry Today: An Introduction to Industrial and Organizational Psychology , 9th Edition, New York, Macmillan Publishing. 
Shahid, B. (2002).An Extension and Evaluation of Job Characteristics, Organizational Commitment and Job Satisfaction in an Expatriate, Quest Worker, Sales Setting. Journal of Personal Selling and Sales Management. V. 22: 1-11.

Soysal, A., Öke, P., Yağar, F., Tunç, M. (2017), “Örgütsel İletişin ve İş Tatmini Düzeylerinin İncelenmesi: Bir Özel Hastane Örneği”. Selçuk Üniversitesi Sosyal Bilimler Enstitüsü Dergisi, C.37: 243-253.

Spector, P. E. (1985). Measurement of human service staff satisfaction: Development of the Job Satisfaction Survey. American journal of community psychology, 13 (6), 693-713.

Spector, P.E. (1997). Job Satisfaction: Application, Assesment, Causes and Consequences. Thousand Oaks, C.A.:Sage Publications.

Tengilimoğlu, D. (2005). Hizmet işletmelerinde liderlik davranışları ile iş doyumu arasındaki ilişkinin belirlenmesine yönelik bir araştırma. Ticaret ve Turizm Eğitim Fakültesi Dergisi, 1 (24): 23-45.

Yelboğa, A. (2007). Bireysel Demografik Değişkenlerin İş Doyumu ile İlişkisinin Finans Sektöründe İncelenmesi. Sosyal Bilimler Dergisi, 4 (2): 1-18.

Yelboğa, A. (2009). Validity and Reliability of the Turkish Version of The Job Satisfaction Survey (JSS). World Applied Sciences Journal, 6 (8):1066-1072.

Yelboğa, A. (2012). Örgütsel Adalet ile İș Doyumu İlişkisi: Ampirik Bir Çalışma (The Relationship Between Organizational Justice and Job Satisfaction: An Empirical Study). Ege Akademik Bakış (Ege Academic Review), 12 (2): 171-182.

Yıldız, N., Yolsal, N., Ay, P., Kıyan, A. (2003). İstanbul Tıp Fakültesi’nde Çalışan Hekimlerde İş Doyumu. İstanbul Tıp Fakültesi Mecmuası, 66 (1), 34-41 